\title{
KEBIJAKAN SOSIAL DALAM PEMBANGUNAN
}

oleh:

\author{
Muhammad Fedryansyah
}

\author{
Program Doktoral Program Studi Ilmu Kesejahteraan Sosial \\ Program Pascasarjana Fakultas Ilmu Sosial dan Ilmu Politik Universitas Padjadjaran \\ Jl. Bukit Dago Utara no. 25 Bandung - 40135 \\ e-mail : fedry_cons@yahoo.com
}

\begin{abstract}
ABSTRAK
Kebijakan sosial dan program pelayanan telah banyak dilakukan oleh pemerintah. Meskipun suatu kebijakan sosial telah dirancang dengan baik, tidak berarti pelaksanaannya akan sesuai dengan tujuan yang diharapkan. Keberhasilan suatu kebijakan dilihat dari bagaimana kebijakan tersebut dapat diwujudkan menjadi pedoman yang lebih aplikatif untuk menjadi panduan dalam implementasi kebijakan tersebut. Penelitian ini bertujuan untuk memberikan gambaran tentang interpretasi kebijakan Peraturan Bupati Sumedang No. 12/2013 oleh aparat pemerintah daerah terkait.

Hasil penelitian menunjukkan bahwa pemahaman aparat pemerintah mengenai kebijakan dilihat dari pemahaman mengenai masalah sosial yang menjadi sasaran dari kebijakan, tujuan dari kebijakan, serta regulasi lain yang terkait dengan kebijakan. Selain itu, pada aspek pilihan implementasi terdapat nilai-nilai dan kriteria yang muncul dari aspek-aspek pilihan. Adapun nilainilai yang muncul adalah equality dan equity, sedangkan kriteria yang muncul adalah effectiveness dan efficiency. Ketika menginterpretasikan kebijakan tersebut, aparat pemerintah juga memahami kendala dalam implementasi kebijakan. Adapun kendala dalam implementasi antara lain kondisi sosial budaya masyarakat, kebijakan pendukung, serta ketersediaan fasilitas pendukung.

Penelitian ini merekomendasikan beberapa hal antara lain pelibatan dinas teknis lain dalam implementasi kebijakan, penyusunan peraturan pendukung, serta memaksimalkan pelibatan masyarakat dan pihak swasta dalam implementasi kebijakan.
\end{abstract}

Kata Kunci: Kebijakan Sosial, Interpretasi Kebijakan, Landasan Nilai

\begin{abstract}
Social policy and program have been conducted by the government. Though an social policy has been designed well, does not mean that its implementation would be in line with the aim of which is expected to.The success of a policy from the point of view of how this policy can be interpreted become a guideline for more applicative to be a guide for the implementation of this policy. This research aims to describe the interpretation of the policy regulations of Bupati Sumedang Number 12/2013 by administrator in Badan Perencanaan Pembangunan Daerah, Dinas Pekerjaan Umum, dan Badan Lingkungan Hidup Sumedang.
\end{abstract}


The results showed that understanding administrator about the policy as seen from the understanding of the social issues that become the targets of the policy, the goals of policy, and other related policies. In addition, there are values and criteria that became the basis for the administrator in determining the choices. Values in choices are equality and equity, while the criteria are effectiveness and efficiency. When interpreting the policy, administrators can also understand the constraints in the implementation of the policy. As for the obstacles in the policy implementation are the community's culture, policy evaluation, and the availability of supporting facilities.

The recommendations of this research are involving more agencies, developing more operational regulation, improving community and private sectors involvement in policy implementation.

Keywords: Social Policy, Policy Interpretation, Value Based

\section{Pendahuluan}

Pembangunan pada hakekatnya bertujuan untuk memperbaiki dan meningkatkan kualitas hidup manusia. Terkait dengan hal tersebut, pembangunan memerlukan cara atau pedoman tindakan yang terarah sehingga perbaikan dan peningkatan kualitas hidup manusia dapat tercapai. Suatu perangkat pedoman yang memberikan arah terhadap pelaksanaan strategi-strategi pembangunan dapat pula disebut sebagai kebijakan. Lebih lanjut, kebijakan yang dirancang untuk peningkatan kesejahteraan masyarakat atau kualitas hidup masyarakat tersebut didefinisikan sebagai kebijakan sosial (Midgley and Livermore, 2009 : x).

Midgley (2009 : 5) kemudian membagi kebijakan sosial kedalam dua aspek. Pertama, kebijakan sosial dipahami sebagai kebijakan dan program yang dijalankan oleh pemerintah, yang didesain untuk meningkatkan kesejahteraan masyarakat atau meningkatkan harkat manusia. Kedua, kebijakan sosial dipahami sebagai kegiatan akademik yang mencakup deskripsi, eksplanasi, dan evaluasi terhadap kebijakan sosial.

Melihat pendapat Midgley tersebut, dapat dikatakan bahwa kebijakan sosial berkaitan dengan kesejahteraan masyarakat atau kesejahteraan sosial. Pandangan tersebut sejalan dengan pendapat Zastrow (2010 : 2) yang mengemukakan bahwa tujuan dari kesejahteraan sosial adalah untuk memenuhi kebutuhan sosial, ekonomi, kesehatan, dan rekreasional pada setiap individu di masyarakat. Untuk mencapai tujuan tersebut, maka dari kebijakan sosial disusun programprogram pelayanan sosial kepada masyarakat.

Lebih lanjut, kebijakan sosial yang dilakukan oleh pemerintah dapat dimaknai secara sempit dan secara luas. Secara sempit, kebijakan sosial yang dilakukan oleh pemerintah antara lain dapat dilihat dari program-program pelayanan sosial dalam bidang kesejahteraan sosial yang dikemukakan oleh Deacon (2002 : 4) yaitu pelayanan sosial 
di bidang kesehatan, pelayanan sosial di bidang pendidikan, pelayanan sosial di bidang perumahan, serta layanan sosial personal. Secara luas, kebijakan sosial dimaknai sebagai kebijakan kesejahteraan sosial (social welfare policy), yakni apa yang dilakukan oleh pemerintah yang mempengaruhi kualitas hidup manusia (Di Nitto, 2003 : 2). Upaya yang dilakukan oleh pemerintah tersebut dikategorikan menjadi public assistance, social insurance, social service, serta isu-isu yang mempengaruhi pemenuhan layanan kesejahteraan sosial.

Terkait dengan kebijakan sosial, terdapat beberapa penelitian yang sudah dilakukan dalam mengkaji kebijakan sosial yang diterapkan oleh pemerintah. Pada umumnya kajian terhadap kebijakan sosial dilakukan untuk mengetahui apakah telah terjadi perubahan atau perbaikan terhadap kondisi kehidupan klien atau kelompok sasaran program. Dengan kata lain, penelitian yang terkait dengan kebijakan sosial tersebut lebih diarahkan pada implementasi dan evaluasi terhadap kebijakan sosial. Penelitian mengenai evaluasi kebijakan dilakukan pada program-program yang dijalankan oleh pemerintah (Mujiyadi dan Sumarno, 2013; Suradi, 2012; Habibullah dan Noviana, 2013; Widodo, dkk., 2010; Sumarno dan Roebiyantho, 2013; Anasiru, 2011; Supeno, 2006). Selain evaluasi kebijakan sosial, penelitian lain mengenai kebijakan sosial diarahkan pada implementasi dari kebijakan sosial (Astuti, 2013; Padmi, dkk., 2013; Purwanto dan Syawie, 2013; Fatony, 2011; Suradi, dkk., 2013). Kesimpulan dari penelitian-penelitian tersebut adalah bahwa kebijakan dan program pelayanan telah banyak dilakukan namun masih terdapat beberapa kendala dalam pelaksanaan program dan pencapaian tujuan program. Meskipun kebijakan sosial, yang menjadi pedoman dalam penyusunan program, telah dirancang dengan baik, tidak berarti pelaksanaannya akan sesuai dengan tujuan yang diharapkan. Dengan kata lain, keberhasilan suatu kebijakan dilihat dari bagaimana kebijakan tersebut dapat diinterpretasikan oleh pihak-pihak yang terkait. Terutama, bagaimana suatu kebijakan diinterpretasikan menjadi pedoman yang lebih aplikatif untuk menjadi panduan dalam implementasi kebijakan tersebut.

Untuk memahami interpretasi pada kebijakan tersebut dapat dilihat dari pandangan Jamrozik mengenai level dalam kebijakan sosial. Jamrozik (2001 : 51-52) menjelaskan bahwa kebijakan sosial merupakan suatu rangkaian proses, yang meliputi tiga level, yaitu level politik (political sphere), level administratif (administrative sphere), dan level operasional (operational sphere). Level politik merupakan proses perencanaan dan formulasi kebijakan (policy planning and formulation). Level administratif merupakan proses interpretasi dan penyusunan kebijakan menjadi serangkaian kegiatan yang lebih operasional. Proses intepretasi tersebut sebagai 
kerangka kerja untuk level operasional dimana pelayanan sosial (service delivery) yang sebenarnya dilaksanakan langsung kepada masyarakat (service-receiving public).

\section{Tinjauan Pustaka}

Tujuan dari kesejahteraan sosial adalah untuk memenuhi kebutuhan sosial, ekonomi, kesehatan, dan rekreasional pada setiap individu di masyarakat (Zastrow, 2010 : 2). Kesejahteraan sosial berupaya untuk meningkatkan keberfungsian sosial pada semua lapisan umur, baik yang tergolong dalam kelompok miskin maupun kelompok kaya. Pandangan yang sedikit berbeda dikemukakan oleh Midgley (1995 : 5) yang melihat kesejahteraan sosial sebagai suatu keadaan atau kondisi kehidupan manusia yang tercipta ketika berbagai permasalahan sosial dapat dikelola dengan baik; ketika kebutuhan manusia dapat terpenuhi dan ketika kesempatan sosial dapat dimaksimalkan.

Pandangan Midgley tersebut menggambarkan tentang pengelolaan masalah sosial yang baik akan dapat mewujudkan kesejahteraan sosial. Selain pengelolaan masalah sosial, kesejahteraan sosial juga dicirikan ketika kebutuhan-kebutuhan manusia dapat terpenuhi. Kebutuhan-kebutuhan tersebut tidak saja kebutuhan dasar (seperti makan, pakaian, dan perumahan), tetapi juga kebutuhan yang melengkapi kebutuhan dasar seperti pendidikan dan kesehatan. Midgley juga menyebutkan bahwa kesejahteraan sosial terwujud ketika kesempatan sosial dapat dimaksimalkan. Melihat pendapat Midgley tersebut, dapat dikatakan bahwa kesejahteraan sosial tidak sekedar bicara tentang keberfungsian sosial individu, namun juga membahas tentang suatu kondisi atau keadaan yang memungkinkan setiap individu mendapatkan layanan-layanan untuk meningkatkan kualitas hidupnya. Dengan demikian, kesejahteraan sosial merupakan suatu keadaan ketika setiap individu mempunyai kesempatan yang sama untuk mengakses layanan-layanan yang terkait dengan upaya pemenuhan kebutuhannya.

Pendapat Midgley tersebut menunjukkan keluasan cakupan kesejahteraan sosial. Untuk memahami keluasan pembahasan kesejahteraan sosial ini, dapat dilakukan dengan memahami keluasan makna dari kebijakan kesejahteraan sosial (social welfare policy) yang disampaikan oleh $\mathrm{Di}$ Nitto. Ditambahkan pula oleh Di Nitto (2003 : 2-4) bahwa kebijakan sosial tersebut merujuk pada tindakan pemerintah yang berdampak pada kesejahteraan masyarakatnya melalui penyediaan layanan dan pendapatan. Pada umumnya, kebijakan sosial dibatasi pada kebijakan pemerintah yang terkait langsung dengan pendapatan, layanan, dan kesempatan bagi mereka yang lanjut usia, miskin, disable, sakit, atau kelompok rentan lainnya. Di Nitto beranggapan bahwa kebijakan sosial itu lebih luas yang dapat dikategorikan menjadi public assistance (karena hanya untuk orang miskin), 
social insurance (karena untuk mencegah orang menjadi miskin), social service (karena untuk menyediakan layanan, pendidikan, dan lainnya), serta isu-isu yang mempengaruhi pemenuhan layanan kesejahteraan sosial.

Dari pendapat Di Nitto tersebut, dapat dilihat bahwa kebijakan sosial merupakan segala tindakan yang diambil pemerintah yang dapat mempengaruhi kesejahteraan masyarakat. Tindakan yang diambil tersebut tidak hanya terfokus pada bidang-bidang pekerjaan sosial melainkan juga pada bidangbidang pembangunan lain yang lebih luas. Dengan kata lain pemerintah bertanggung jawab dalam memberikan layanan kepada masyarakat miskin; memberikan jaminan kepada masyarakat supaya tidak jatuh miskin; menyediakan layanan-layanan kepada seluruh masyarakat dalam meningkatkan kualitas hidup masyarakat; serta isu-isu yang terkait secara langsung maupun tidak langsung dengan upaya pemenuhan layanan yang dilakukan oleh pemerintah tersebut.

Pandangan Di Nitto mengenai keluasan kebijakan kesejahteraan sosial tersebut, juga sejalan dengan pendapat Gilbert and Terrell (1993 : 33) bahwa kebijakan kesejahteraan sosial dipahami secara komprehensif. Pemahaman secara komprehensif tersebut dapat dilihat berdasarkan kategori bidang fungsional (seperti misalnya bidang kesehatan, pengadilan, pendidikan), area masalah (seperti misalnya kekerasan domestik, tuna wisma, pengangguran), kelompok populasi (seperti misalnya anak-anak, remaja, lanjut usia), atau kombinasi dari ketiganya. Meskipun, ditambahkan oleh Gilbert and Terrell, bahwa seringkali ketiga kategori tersebut saling tumpang tindih sehingga akan menyulitkan dalam pemisahan secara substantif. Dapat dilihat bahwa kebijakan kesejahteraan sosial terkait dengan program pelayanan yang dilakukan oleh pemerintah pada tiga kategori tersebut.

Untuk memahami pandangan dari Di Nitto dan Gilbert and Terrell tersebut, dapat dilihat pula dari pandangan Spicker (1995 : 3) yang menyebutkan bahwa kebijakan sosial merupakan kajian tentang pelayanan sosial dan negara kesejahteraan. Meskipun kajian tersebut tersebut mengalami perkembangan, akan tetapi pelayanan sosial merupakan awal dari kajian kebijakan sosial dan masih menjadi inti dari kajian tersebut. Pandangan Spicker ini menjelaskan bahwa kebijakan sosial merupakan kajian tentang pelayanan sosial dalam negara kesejahteraan. Lebih lanjut, Spicker menjelaskan bahwa pada prinsipnya layanan tersebut merupakan tanggung jawab pemerintah di seluruh negara, bukan hanya pemerintah pada negara kesejahteraan. Dalam hal ini dapat diartikan bahwa layanan tersebut juga disediakan oleh negara yang tidak termasuk dalam kategori negara kesejahteraan. Semua negara atau pemerintahan akan bertujuan untuk meningkatkan kesejahteraan masyarakatnya. Jadi kajian tentang kebijakan sosial tidak hanya kajian tentang pelayanan 
sosial yang diberikan dalam negara kesejahteraan, tapi juga pelayanan sosial yang diberikan oleh semua negara dalam rangka meningkatkan kesejahteraan masyarakatnya.

Dari pandangan Spicker tersebut dapat dilihat bahwa peningkatan kesejahteraan masyarakat melalui penyelenggaraan pelayanan sosial merupakan tujuan yang ingin dicapai dalam kebijakan sosial. Pandangan tersebut dapat menjelaskan pendapat Midgley sebelumnya di atas, mengenai kesejahteraan sosial dalam arti yang luas. Dimana, kebijakan sosial muncul ketika pemerintah berupaya untuk mengelola permasalahan sosial; menyediakan layanan yang terkait dengan pemenuhan kebutuhan dan menjamin layanan tersebut dapat dijangkau oleh seluruh masyarakat.

Pemikiran ini diperkuat oleh pandangan Blackmore and Griggs (2007 : 1), yang mendefinisikan tujuan kebijakan sosial sebagai upaya untuk meningkatkan kesejahteraan sosial (meskipun seringkali mengalami kegagalan) serta untuk memenuhi kebutuhan individu seperti pendidikan, kesehatan, perumahan, dan jaminan sosial. Pemenuhan kebutuhan individu dan peningkatan kesejahteraan sosial ini menunjukkan bahwa nilai keadilan sosial sangat kental dalam kebijakan sosial.

Dari pandangan tersebut, dapat dilihat bahwa kebijakan sosial memiliki dua sasaran utama yakni peningkatan kesejahteraan sosial dan pemenuhan kebutuhan individu.
Pemisahan dua sasaran tersebut menunjukkan bahwa kebijakan sosial tidak hanya terkait dengan layanan-layanan dalam bidang pendidikan, kesehatan, perumahan, dan jaminan sosial. Melainkan juga dengan upayaupaya yang mendorong terciptanya kesejahteraan sosial di masyarakat.

Pandangan lain mengenai pemahaman kebijakan sosial juga dapat dilihat dari pendapat Jamrozik mengenai definisi kebijakan sosial. Kebijakan sosial dikemukakan oleh Jamrozik (2001 : 37) sebagai sebuah mekanisme untuk mengalokasikan sumberdaya yang ada pada masyarakat dengan tujuan untuk mencapai outcome tertentu sesuai harapan nilai-nilai dominan masyarakat serta tujuan dan sasaran kebijakan yang telah ditentukan.

Lebih lanjut, dijelaskan oleh Jamrozik bahwa kebijakan sosial pada hakekatnya berurusan dengan pengaturan hubungan sosial yang bertujuan untuk menegaskan nilai-nilai dan kepentingan tertentu. Hal tersebut dilakukan melalui implementasi pendekatan yang sesuai yang didesain untuk mencapai hasil yang diharapkan.

Berbeda dengan Jamrozik, Midgley and Livermore (2009 : 5) membagi kebijakan sosial kedalam dua aspek. Pertama kebijakan sosial dipahami sebagai kebijakan dan program yang dijalankan oleh pemerintah, yang didesain untuk meningkatkan kesejahteraan masyarakat atau meningkatkan harkat manusia. Kedua, kebijakan sosial 
dipahami sebagai kegiatan akademik yang mencakup deskripsi, eksplanasi, dan evaluasi terhadap kebijakan sosial.

Pandangan Midgley tersebut diperkuat oleh pendapat Deacon (2002 : 4-8) yang menyatakan bahwa kebijakan sosial sebagai suatu kajian dan analisis seringkali dipandang tidak memiliki hubungan yang erat dengan ilmu sosial lainnya seperti ilmu ekonomi, ilmu sosiologi, dan ilmu politik. Namun, pandangan tersebut terbantahkan ketika melihat pada manfaat dari jaminan sosial atau administrasi dari sistem layanan kesehatan. Pendukung kajian kebijakan sosial justru melihat bahwa kajian tersebut memiliki hubungan yang erat dengan ilmu sosial lainnya ketika mewujudkan kesejahteraan sosial masyarakat, dengan menggunakan kerangka kerja analitisnya dan penekanan pada isu keadilan sosial dan kebutuhan manusia.

Bahasan dan kajian kebijakan sosial dapat dilihat dari beragam cara dan saling mengikat satu dengan lainnya. Pada satu sisi, ini merupakan kebijakan dan praktik dalam menyelenggarakan layanan kesehatan, layanan jaminan sosial atau perlindungan sosial, layanan pendidikan, dan layanan perumahan. Sementara kajian kebijakan sosial ini dianggap sebagai bagian dari sektor kebijakan yang dikembangkan di negara-negara kesejahteraan, kajian ini mulai tumbuh dan diterapkan di negara-negara yang sedang berkembang (Hall and Midgley, 2004; Mkandawire, 2005). Ketika diterapkan di negara-negara tersebut, perlu dilakukan modifikasi untuk mengubah kerangka berpikir dan merangkul masyarakat miskin sehingga kesejahteraan sosial dapat diwujudkan (Gough and Woods, 2004). Karena itu kajian kebijakan sosial merupakan bagian dari kajian negara kesejahteraan dan kajian pembangunan pada pengembangan negara kesejahteraan. Pemisahan kedua konsep tersebut akan mengaburkan tentang pemahaman kajian pembangunan di negara kesejahteraan serta kebijakan sosial dalam konteks pembangunan yang hanya fokus pada kemiskinan, akibatnya akan melupakan isu keadilan dan universalisme. Dari pemaparan di atas dapat disimpulkan bahwa kebijakan sosial memiliki dua sasaran utama yakni peningkatan kesejahteraan sosial dan pemenuhan kebutuhan individu yang terkait dengan layanan dalam bidang pendidikan, layanan dalam bidang kesehatan, layanan dalam bidang perumahan, dan layanan jaminan sosial.

\section{Metodologi}

Penelitian ini menggunakan pendekatan kualitatif, untuk mencari informasi yang mendalam tentang interpretasi yang dilakukan di level administratif mengenai kebijakan sosial yang disusun oleh pemerintah Kabupaten Sumedang. Informasi yang mendalam mengenai intepretasi kebijakan di level administratif tersebut dilihat dari pemahaman aparat pemerintah mengenai kebijakan Peraturan Bupati Sumedang Nomor 12 Tahun 2013 tentang Rencana Tata 
Bangunan dan Lingkungan Kawasan Strategis

Provinsi Pendidikan Jatinangor.

Penelitian ini mendeskripsikan mengenai interpretasi kebijakan Peraturan Bupati Sumedang Nomor 12 Tahun 2013 tentang Rencana Tata Bangunan dan Lingkungan Kawasan Strategis Provinsi Pendidikan Jatinangor, yang dilakukan oleh aparat pemerintah di level administratif. Interpretasi tersebut dilihat dari pemahaman mengenai masalah sosial dan tujuan yang tercantum dalam suatu kebijakan; serta pemahaman mengenai regulasi yang terkait dengan kebijakan tersebut. Selain itu juga dilihat dari nilai-nilai (equality, equity, dan adequacy) dan kriteria tunggal (effectiveness, efficiency, cost ffective, atau cost benefit) yang muncul dari pilihan-pilihan yang diambil oleh aparat pemerintah dalam menginterpretasikan kebijakan. Nilai-nilai tersebut muncul dalam pilihan aparat pemerintah mengenai bases allocation dan social provision. Sedangkan, kriteria tunggal muncul ketika menetapkan pilihan mengenai delivery system dan finance.

\section{Hasil}

Interpretasi kebijakan Peraturan Bupati Sumedang Nomor 12 Tahun 2013 Tentang Rencana Tata Bangunan dan Lingkungan Kawasan Strategis Provinsi Pendidikan Jatinangor yang dilakukan oleh aparat pemerintah, antara lain dilihat dari pemahaman aparat pemerintah, pilihan implementasi yang diambil, serta kendala implementasi yang dirasakan. Adapun pemahaman aparat pemerintah ketika menginterpretasikan kebijakan tersebut antara lain pemahaman mengenai masalah sosial yang menjadi sasaran kebijakan, pemahaman mengenai tujuan kebijakan, serta pemahaman mengenai regulasi terkait. Sedangkan pilihan yang diambil terkait dengan aspek-aspek penentuan penerima program, penentuan program, penentuan penyampaian program, serta penentuan pendanaan. Selain itu, juga ditemukan adanya kendala implementasi yang dirasakan oleh aparat pemerintah ketika menginterpretasikan Peraturan Bupati Sumedang Nomor 12 Tahun 2013 tersebut.

Peraturan Bupati Sumedang Nomor 12 Tahun 2013 Tentang Rencana Tata Bangunan dan Lingkungan Kawasan Strategis Provinsi Pendidikan Jatinangor merupakan suatu kebijakan sosial yang dikeluarkan oleh Pemerintah Kabupaten Sumedang. Pendapat ini mengacu pada pandangan Di Nitto mengenai kebijakan sosial. Di Nitto (2003) menyebutkan bahwa kebijakan sosial merupakan segala tindakan yang dilakukan oleh pemerintah yang mempengaruhi kualitas hidup masyarakat. Pemerintah bertanggung jawab dalam memberikan layanan kepada masyarakat miskin, memberikan jaminan kepada masyarakat supaya tidak jatuh miskin, serta menyediakan layanan-layanan kepada seluruh masyarakat dalam meningkatkan kualitas hidup masyarakat. Dengan demikian, dapat dikatakan bahwa melalui Peraturan 
Bupati Nomor 12 Tahun 2013 tersebut, pemerintah Kabupaten Sumedang berupaya untuk menyediakan layanan kepada masyarakat Jatinangor dengan tujuan untuk meningkatkan kualitas hidup masyarakat Jatinangor.

Selain dilihat dari pendapat Di Nitto, pandangan dari Blackmore and Griggs (2007) juga dapat dijadikan sebagai acuan ketika menyebutkan bahwa kebijakan tersebut termasuk sebagai kebijakan sosial. Pandangan Blackmore and Griggs tersebut lebih menekankan pada peran pemerintah dalam menangani masalah sosial. Dimana, peran tersebut muncul dalam bentuk kebijakankebijakan yang dikeluarkan oleh pemerintah. Peraturan Bupati Nomor 12 Tahun 2013 itu sendiri diarahkan untuk mengatasi masalahmasalah sosial yang ada di Jatinangor seperti antara lain pemukiman yang padat; banjir; pemenuhan air minum dan air bersih; serta persampahan. Ketika masalah-masalah tersebut dapat diatasi oleh pemerintah, maka peningkatan kualitas hidup masyarakat Jatinangor akan dapat tercapai. Dimana, masyarakat Jatinangor akan mendapatkan kualitas hidup yang layak, yang dilihat dari pemukiman yang tertata, akses layanan air bersih yang baik, pengelolaan sampah yang baik, serta terhindar dari masalah banjir.
Pemahaman aparat pemerintah mengenai Peraturan Bupati Sumedang Nomor 12 Tahun 2013 dapat dilihat dari pemahaman aparat pemerintah mengenai tujuan dari kebijakan tersebut. Pemahaman mengenai tujuan kebijakan juga tidak dapat dilepaskan dari pemahaman aparat pemerintah mengenai masalah sosial yang menjadi sasaran; serta pemahaman mengenai regulasi yang terkait.

Landasan nilai dalam interpretasi kebijakan Peraturan Bupati Sumedang Nomor 12 Tahun 2013 dilihat dari kategori pilihan yang antara lain bases allocation, social provision, delivery system, dan finance. Pada kategori bases allocation menunjukkan bahwa aparat pemerintah memilih target sasaran yang bersifat universal. Kemudian, pada kategori social provision, aparat pemerintah memilih program dan layanan yang bersifat concrete and diversified. Dari aspek pilihan bases allocation dan social provision tersebut, nilai yang muncul adalah equality dan equity. Pada kategori delivery system, pilihan yang diambil adalah public, private, and free-standing, sedangkan, kategori finance pilihannya adalah fixed-amount block grant. Dari aspek pilihan delivery system, dan finance tersebut, kriteria yang muncul adalah effectiveness dan efficiency.

Dari hasil penelitian juga dapat disimpulkan adanya kendala implementasi ketika menginterpretasikan kebijakan Peraturan Bupati Sumedang Nomor 12 Tahun 2013, antara lain perilaku masyarakat, 
kebijakan pendukung, dan ketersediaan fasilitas pendukung.

\section{Daftar Pustaka}

Alcock, P., Erskine, A., and May, M. 2003. "The Students' Companion to Social Policy". Oxford : Blackwell.

Alston, Margaret and Wendy Bowles. 1998. "Research for Social Workers an Introduction to Methods". Sydney : NSW.

Anasiru, Ronawati. 2011. "Implementasi Model-Model Penanggulangan Anak Jalanan di Kota Makassar". Sosiokonsepsia. Vol. 16 No. 02.

Astuti, Mulia dkk. 2013. "Kebijakan Kesejahteraan dan Perlindungan Anak : Studi Kasus Evaluasi Program Kesejahteraan Sosial Anak di Provinsi DKI Jakarta, DI Yogyakarta, dan Provinsi Aceh". Jakarta : P3KS.

Babbie, A. R. 2005. "Research Methods for Social Work". Belmont: Thomson Brooks/Cole.

Bappeda Kabupaten Sumedang. 2009. "Laporan Akhir Studi Kelayakan Kawasan Jatinangor Sebagai Kawasan Perkotaan”.

Bappeda Kabupaten Sumedang. 2013 "Profil Daerah Kabupaten Sumedang Tahun 2013".

Blackmore, Ken. and Edwin Griggs. 2007. "Social Policy an Introduction". New York : McGraw-Hill.

Chambers, Donald E. and Kenneth R. Wedel. 2005. "Social Policy and Social Programs : a Method for the Practical Public Policy Analyst". Boston : Pearson Education Inc.

Chambers, Donald E., Kenneth R. Wedel, and Rodwell M., 1992. "Evaluating Social Programs". Boston : Allyn and Bacon.

Colby, Ira C. 2008. "Comprehensive Handbook of Social Work and
Social Welfare (Social Policy and Policy Practice)". John Wiley\&Sons, Inc.

Creswell, J. W. (2002). "Desain Penelitian Kualitatif". Jakarta: KIK Press.

Deacon, Alan. 2002. "Perspectives on Welfare". Buckingham: Open University Press.

Di Nitto, Diana M. 2003. "Social Welfare Politics and Public Policy".USA : Allyn and Bacon.

Dobelstein, Andrew W. 1991."Social Welfare Policy and Analysis". Chicago : Nelson-Hall Publishers.

Dubois, Brenda. Karla Krogsrud Miley. 2010. "Social Work : An Empowering Profession". Boston: Pearson Education Inc.

Ellis, Rodney A. 2008. "Policy Practice" dalam Colby, Ira C. 2008. "Comprehensive Handbook of Social Work and Social Welfare (Social Policy and Policy Practice)". John Wiley\&Sons, Inc.

Fatony, Achmad. 2011. "Kebijakan Pengentasan Kemiskinan Berbasis Participatory Poverty Assessment : Kasus Yogyakarta”. Sosiokonsepsia. Vol. 16 No. 02.

Friedlander, Walter. 1980. "Introduction to Social Welfare". Englewood Cliffs, NJ : Prentice Hall

Gilbert, Neil dan Paul Terrel. 1993. "Dimensions of Social Welfare Policy". Massachusetts: Allyn and Bacon.

Gough, Ian. and Geof Wood. "Welfare Regimes : Linking Social Policy to Social Development". http://www.staff.bath.ac.uk.

Habibullah, dan Ivo Noviana. 2013. "Kebijakan Pendamping Program Keluarga Harapan”. Jakarta : P3KS.

Hall, Anthony \& James Midgley. 2004. "Social Policy for Development". London: Sage Publications.

http://pkh-

sumedang.blogspot.com/2011_03_ 01_archive. html 
Jansson, B. 2008. "Becoming an Effective Policy Advocate : form Policy Practice to Social Justice". Pacific Groove, CA : Brooks/Cole.

Jamrozik, Adam. 2001. "Social Policy in The Post-Welfare State : Australians on The Threshold of The 21st Century. Australia : Longman.

Jamrozik, Adam \& Nocella, Luisa. 1998. "The Sociology of Social Problems : Theoretical Perspectives and Methods of Intervention". Cambridge : Cambridge University Press.

Kirst-Ashman, Karen. 2010. "Introduction to Social Work and Social Welfare : Critical Thinking Perspective". Canada: Brooks/Cole, Cengage Learning.

Kwok, Joseph Kin Fun. 2008. "Social Justice for Marginalized and Disadvantaged Groups" dalam Colby, Ira C. 2008. "Comprehensive Handbook of Social Work and Social Welfare (Social Policy and Policy Practice)". John Wiley\&Sons, Inc.

Mendoza, Thelma Lee. 1981. "Social Welfare and Social Work, an Introduction". Cebu City : E.Q. Cornejo\&Sons.

Midgley, James. 1995. "Social Development : The Developmental Perspective in Social Welfare". London : SAGE Publications Ltd.

Midgley, James and Michelle Livermore. 2009. "The Handbook of Social Policy". California : SAGE Publications Ltd.

Midgley, James and Michael Sherraden. 2009. "The Social Development Perspectives in Social Policy". Dalam James Midgley, Martin B. Tracy dan Michelle Livermore (ed), The Handbook of Social Policy. London: Sage.

Minichiello, Victor R. A. 1995. "In-Depth Interviewing". Melbourne Australia: Longman.
Mkandawire, T. 2005. "Social Policy in a Development Context". Geneva: UNRISD

Mujiyadi, B. dan Setyo Sumarno. 2013. "Evaluasi Program Bedah Kampung”. Jakarta : P3KS.

Neuman, Laurance. W. 2006. "Social Research Methods". Boston: Allyn and Bacon.

Padmi, Teti Ati, dkk. 2013. "Studi Kebijakan Penanggulangan Bencana Alam Berbasis Masyarakat : Studi Kasus Kampung Siaga Bencana dalam Mengurangi Resiko Bencana Alam, di Kota Padang, Provinsi Sumatera Barat dan Kabupaten Sleman, Provinsi D.I. Yogyakarta”. Jakarta : P3KS.

Purwanto, Agus Budi dan Moch. Syawie. 2013. "Kebijakan Pembangunan Kesejahteraan Sosial di Daerah Perbatasan Antar Negara : Studi di Kabupaten Sambas, Kalimantan Barat”. Jakarta : P3KS.

Rein, Martin. 1983. "From Policy to Practice". London : Macmillan.

Rubin, Allen and Earl R. Babbie. 2008. "Research Methods for Social Work". Belmont: Thomson Brooks/Cole.

Spicker, Peter. 1995. "Social Policy: Themes and Approaches". London : Prenctice Hall.

Stein, Theodore J. 2001. "Social Policy and Policy Making: The Branches of Government and the Public-atLarge". New York : Columbia University Press.

Suharto, Edi. 2005. "Analisis Kebijakan Publik". Bandung: Alfabeta.

Sumarno, Setyo dan Haryati Roebiyantho. 2013. "Evaluasi Program Keserasian Sosial dalam Penanganan Konflik Sosial”. Jakarta : P3KS.

Supeno, Eko. 2006. “Implementasi Kebijakan Jaring Pengaman Sosial-Operasi Pasar Khusus Beras (JPS-OPKB) Keluarga Pra Sejahtera”. 
Masyarakat, Kebudayaan, dan Politik. Vol. 19 No. 1.

Suradi, dkk. 2013. "Kebijakan Pemberdayaan Sosial Komunitas Adat Terpencil". Jakarta : P3KS.

Suradi. 2012. "Studi Evaluasi Dampak Kebijakan Sosial : Rehabilitasi Sosial Rumah Tidak Layak Huni bagi Keluarga Miskin di Kota Banjarmasin". Sosiokonsepsia. Vol. 17 No. 02.

Thompson, Neil. 2005. "Understanding Social Work : Preparing for Practice". New York : Palgrave Macmillan.

Weimer, D. and Vining, A. 1992. "Policy Analysis : Concepts and Practice".
Englewood Cliffs, NJ : Prentice Hall.

Widodo, Nurdin. Ruaida Murni., Anwar Sitepu., Togiaratua Nainggolan. 2010. "Studi Kebijakan Pengembangan Kegiatan Satuan Bakti Pekerja Sosial di Panti Sosial Masyarakat". Jakarta : P3KS.

Zastrow, Charles. 2010. "Social Work and Social Welfare". Canada: Brooks/Cole, Cengage Learning. 